\title{
Alienation and Existential Predicaments of Clones: Interpreting Never Let Me Go in the Context of Posthumanism
}

\author{
WEI Li, YUAN Jing-jing \\ Inner Mongolia University, Hohhot, China
}

\begin{abstract}
The literary background of Kazuo Ishiguro's novel Never Let Me Go sets in a highly developed scientific and technological world where clones are created by human and "educated" in the Hailsham School for the sake of “donating” their vital organs to human three or four times before death. By depicting miserable fate of clones, the novel conveys deep concerns on the consequences of abusing technology in modern society. Ever since the burgeoning development of life science and artificial intelligence in the 1990s, the trend of posthumanism/transhumanism has emerged. Posthumanism promotes approaches to enhancing human body condition and organism, and extending human lifespan to augment human capacity and well-being by the advancement of technology. In literary field, contemplation on the relationship between human beings and technology has become a major concern of posthumanism. Putting Never Let Me Go in the context of posthumanism, this essay probes into the significant themes of the novel from three aspects: (1) clones' torments in the existential predicaments imposed by human; (2) human's violation to the principles of bioethics causing the existential predicaments of alienated clones; (3) appealing to human to ruminate on the relationship between scientific technology and ethics.
\end{abstract}

Keywords: posthumanism, Never Let Me Go, human clones, alienation, existential predicaments, bioethical principles

\section{Introduction}

The literary writing of the Japanese-born British novelist Kazuo Ishiguro (1954-) has drawn increasing attention since he won the Nobel Prize for literature in 2017, by establishing his prestige for profundity, delicacy, and uniqueness in “international theme”. Ishiguro's prolific productions have gained extensive literary criticisms especially in terms of hybrid styles and ingenious subversion of traditional genres. Among his six award-winning novels, Never Let Me Go (2005) is unparalleled by others in its depiction of human psyche and exploration of the universal themes such as what it means to be human. It was shortlisted for the 2005 Man Booker Prize for fiction and the 2005 National Book Circle Award. Time Magazine named it the best novel of 2005 and included it in Time 100 Best English-Language Novels from 1923 to 2005. Setting in the background of a modern world where science and technology are highly developed, Never Let Me Go depicts the miserable

WEI Li, Ph.D., Professor, Foreign Languages College, Inner Mongolia University, Hohhot, China.

YUAN Jing-jing, postgraduate student, Foreign Languages College, Inner Mongolia University, Hohhot, China. 
fate of the clones in the Hailsham School. Through the first-person narration of the protagonist Kathy (also a clone), clones are created by human and "educated" in a boarding school named "Hailsham" for the sake of their organ donations to human three or four times before death. Ostensibly it is for the purpose of education, but there hides a dark offense in the whole project at Hailsham. The Hailsham is completely an "Organ Culture Laboratory" or a "Human Factory" where the clones are sheltered just because their vital organs are in urgent need of human beings. The organ deprivation is labeled as "Donation", and the death of a clone is called “completion”. Although Never Let Me Go reads superficially like scientific fiction, various criticisms have explored its multi-dimensional significances beyond that. In western literary field, abundant researches have testified the novel in diverse approaches, mainly focusing on class privilege (Robbins, 2007), ethical implications (Roos, 2008), unconventional genre, narrative techniques and existential inquiries (Griffin, 2009), linguistic features (Pandey, 2011), aesthetic features (Mazullo, 2012), post-colonial theory (Vichinensing, 2017), structuralist analysis (Quach, 2017), and posthumanism aspect and dystopian tradition (Kashi \& Ladani, 2017). In the line with similarly keen interests to the novel, scholars in Chinese literary field have recently conducted research on it from the perspectives of landscape analogy (Tseng, 2011), Foucauldian power mechanism (Wang, 2014), Bentham's model of panopticon (Li \& Wang, 2014), existentialism (Zhang, 2014), and discourse functions (Su \& Huang, 2014).

In terms of its profound themes, Never Let Me Go primarily concerns with the fate of human clones in the era of rapid development of genetic engineering. When touching on genetic engineering, it perceptibly provokes and revives a variety of debates on the issues of animal cloning and human cloning. Indeed, cloning technology has developed into the stage of human cloning just in recent years, but it has inevitably involved in a controversial topic of how to draw a clear boundary between science and bioethics, since biotechnology tends to threaten moral and ethical values of human beings if being misapplied. One of the most startling incidents of the violation of bioethics is in "the scientific scandal of He Jiankui's gene-editing babies"1 in 2018. More than 100 Chinese scientists issued a joint statement strongly condemned that the gene-editing of human embryo is both a serious violation of research ethics and an ethical misconduct. The driving force hidden behind this scientific scandal lies in an expediential excuse that human beings have a desire of employing science and technology to edit genes to create "superhuman", which might help them enhance resistance todisease, improve intelligence, and even extend life span. From another perspective, it also indicates that human beings are worried about the limits of their biological lives and future destiny in the context of posthumanism.

The study of this essay, with deep concerns about the future development of genetic engineering in association with the literary theme of Never Let Me Go, devotes to interpreting the miserable existential predicaments of clones in the novel, by employing the principles of bioethics proposed in 1970s as an innovative angle in the context of posthumanism. It aims to discuss how human beings in the novel violate the principles of bioethics causing the existential predicaments of alienated clones, and examines how clones passively suffer torments in their existential predicaments compelled by human.

\footnotetext{
${ }^{1}$ He Jiankui, a Chinese scientist, shocked the world by claiming the first genetically edited babies were born in China on November 26th, 2018. This move immediately sparked widespread international outrages and condemns. According to the Genetic Engineering \& Biotechnology News on January 21st, 2019, "This behavior serious violates ethics and scientific research integrity, and serious violates relevant state regulations” (Kevin, 2019). At the same time, He Jiankui’s germline editing ethics article was retracted by The CRISPR Journal.
} 


\section{Emergence of Posthumanism}

With the accelerating development of life science technology and artificial intelligence in the late 20th century, human beings began to explore high-tech means to make up for their individual defects, overcome human body limits, enhance intellectual faculties, and prolong human life time in pursuit of power, happiness, and immorality. The trend of posthumanism emerges at this historic moment. With the decreasing tendency of traditional humanism, posthumanism has focused on new ways of understanding human subject, because "the new post-humanist technology will fundamentally subvert humanism” (Harari, 2017, p. 249). Therefore, the emergence of "posthumanism" is also deemed as a deconstruction of the concept of "man" in "humanism".

As a leading figure of posthumanism, Max More held a view that the rapid development of science and technology is accelerating the transformation of human beings into post-human beings in his 1994 article entitled "On Becoming Posthuman”. People might feel astonished in reading More’s statements that "clearly we have already taken our first steps along the road to posthumanity" (More, 1994, p. 39), and "we are not the zenith of nature's development. It is time for us to consciously take charge of ourselves and to accelerate our transhuman progress” (More, 1994, p. 41). Like Nietzsche, More argued that human evolution to higher forms is an inexhaustible process and human beings are predestined to be "evolved (as an overman)". In Mervyn F. Bendle's article entitled "Teleportation, Cyborgs and the Posthuman Ideology", he maintained that as "humanism” being transformed into "posthumanism", there comes "Resurgent Prometheanism” (Bendle, 2002, p. 3) in the era of posthumanism. According to his viewpoint, human beings can change their own destiny instead of subserviently following the mechanical laws of nature. Among of the influential scholars relevant to posthumanist studies, Luca Valera expounds the function of technology in posthumanist time in a recently released article "Posthumanism: Beyond Humanism?”. He directly articulates that “in posthumanist point of view, technology is not configured as an extrinsic way through which the living being progressively eliminated its limitation, but rather, as an intrinsic possibility of living being” (Valera, 2014, p. 486). In the above-cited statements, it appears that science and technology have inevitably been incorporated into the progress and the evolution of human lives. In other words, anthropocentric worldviews have been challenged by many possibilities in the context of posthumanism.

In such circumstances, people began to think prudently about the relationship between human beings and technology at multiple levels. On the one hand, the development of life science and technology in the 20th century, to a certain extent, enables human beings to overcome the limitations of human lives and living conditions; on the other hand, posthumanism trend has had far-reaching effects in the areas of humanism, philosophy, literature, and film industry. Literature concerns social reality and human destiny. The viewpoints of posthumanism have simultaneously exerted multidimensional influences on the creative writing in literature and culture. In recent decades, scientific and fictional works have flourished and entered the fields of literature and film industry, such as Brave New World, The Three-Body Problem, Venom, The Matrix, and Black Mirror and so on. Never Let Me go stands and shines brightly among them. 


\section{Violation of the Bioethical Principles}

Posthumanists accentuate the importance of respecting individual life, and more precisely, of respecting all kinds of life forms. As one of the pioneering post-humanists, Francis Fukuyama, notes his points from the perspective of human nature in his book Our Posthuman Future:

Human nature is what gives us a moral sense, provides us with the social skills to live insociety, and serves as a ground for more sophisticated philosophical discussions of rights, justice, and morality. Instability comes from any alteration to our shared human nature, which is another way of saying that difference leads to instability by creating a situation where communication and dialogue become impossible. (Steven, 2005, p. 5)

This quote apparently indicates that human nature is crucial element for human beings to develop a platform of equal communication, social justice, and moral criterion. It is echoed in the alike expression that "Posthumanism is consistent with perspectives in animal ethics that seek to diminish the meaning and value of claims that species boundaries should have any bearing on our moral commitment to other life forms” (Miah, 2009, p. 72).

In Never Let Me Go, all clones living in Hailsham are depicted as human beings, possessing emotion and self-awareness, and being educated and empowered artistic creative abilities (in the novel, the clones are required draw paintings in class). Are clones in Never Let Me Go human or nonhuman? Regarding the physical constitution, the body of a clone is identical to that of a human being. They have sensitivity and intelligence as ordinary human beings. If we cannot totally tell the differences between human and human clones, then human's replicating and controlling of clones would definitely run counter to the concept of human civilization. Human clones serve for human beings' interests (in the novel, the clones are created to donate vital organs to humans), but are treated as slaves and the objects of exploitation. They serve and sacrifice wholly for the benefits of human beings. This undoubtedly violates the bioethical principles.

Renowned American bioethicists Tom Beauchamp and James Childress in 1979 proposed the widely acknowledged four principles of bioethics, namely, "Principle of Respect for Autonomy, Principle of Beneficence, Principle of Non-maleficence and Principle of Justice” (Beauchamp \& Childress, 2013). In their co-authored book Priciples of Biomedical Ethics, the concept of "Principle of Bioethics" initially appeared and was primarily applied in the medical field. However, this book is "overly accommodating of existing moral beliefs and is distinguished by its emphatic embrace of common morality as the ultimate source of moral norms" (DeGrazia, 2003, p. 219). The four principles are presently used in modern bioethical decision and taken as the foundation for current bioethical debates. Among which, as the first and basic one, "Principle of Respect for Autonomy" refers to respecting for individual rights of independent choice and decision, affirming dignity and equality in communication.

In Never Let Me Go, clones are isolated to grow up in Hailsham, prohibited to cross the school boundary, managed to wear a monitor (an electronic ID bracelet) for health check, and infused their innate obligation to organ donation. Teachers in Hailsham are "guardians" to clones all the time, scrutinizing clones' behavior and health condition. Teacher Miss Lucy irrepressibly tells the truth in a class that all students in Hailsham are cloned identical to human and raised up to provide organs, with survival time of donating organs three or four times to human. From the perspective of bioethics, this is a serious violation of "Principle of Respect for Autonomy" as 
human clones are unable to own rights of choice. In one aspect, the individual freedom of clones is restricted and deprived. All clones are not allowed to leave the school until they "graduated" from Hailsham. But after graduation, they are assigned to a designated area and wait to be informed of the beginning of donation. From the moment of being cloned and being created, their bodiesand lives cannot belong to themselves. The only purpose of their existence is to provide organs for human beings. In another aspect, passive and gratuitous organ donations are harmful and fatal to their lives, which further violate "Principle of Non-maleficence" in the principles of bioethics. In Chapter 23, knowing Tommy’s upcoming fourth donation notice, Kathy falls into a sentimental mood:

How maybe, after the fourth donation, even if you've technically completed, you're still conscious in some sort of way; how then you find there are more donations, plenty of them, on the other side of that line; how there are no more recovery centres, no carers, no friends; how there's nothing to do except watch your remaining donations until they switch you off. It's horror movie stuff, and most of the time people don't want to think about it. (Ishiguro, 2006, p. 279)

In this cited paragraph, Kathy’s sentimental words reflect a compathy of helplessness, horror, and despair with her fellow clones. "Principle of Non-maleficence" is the ethical baseline ofnon-restricted and equal interactions, but in Never Let Me Go, human beings unscrupulously breached this baseline, arbitrarily put clones in an unequal position, and cruelly trampled clones' lives. Synchronously, this act is a demonstration of violating the "Principle of Justice", because "to admit the similarity of clones as human beings is equivalent to ‘endow’ clones with human nature, thus equating human beings’ behavior with killing lives” (Xin, 2012, p. 134).

\section{Existential Predicaments of Clones}

In Never Let Me Go, clones are subjected to existential predicaments resulting from isolation, horror, and predestined death. Although being portrayed as human beings having emotions and dreams, they are irresistible to non-humanized fate. In Chapter 7, Peter expressed to fellow clones his dream of becoming an actor in America in the future, and Miss Lucy noted:

None of you will go to America, none of you will be film stars. And none of you will be working in supermarkets as I heard some of you planning the other day. Your lives are set out for you. You'll become adults, then before you are old, before you're even middle-aged, you'll start to donate your vital organs. That's what each of you was created to do...You were brought into this world for a purpose, and your futures, all of them, have been decided. (Ishiguro, 2006, p. 81)

Miss Lucy uncovered a brutal truth. Human clones are indoctrinated since an early age how "special" they are, and why they are needed to stay healthy to fulfill their missions - their lives will be "completed" on finishing organ donations, and they cannot bear babies. This predestined death hauntes all clones and deprives them of all privileges to make their own choices. There is a heartbroken scene in Chapter 6, when Kathy "grabbed a pillow to stand in for the baby" and was doing slow dance and singing along in her room "Oh baby, baby, never let me go...” (Ishiguro, 2006, p. 71). Ironically, the apathetic Madame was sobbing in the doorway in watching the scene, but such tears are merely instantaneous. Clones are molded as human but are dehumanized by human, because what human beings are driven is the interest in sacrificing clone's life to prolong their own life.

Another scene is connected to the annual Spring Exchangein Hailsham, a time for human clones to demonstrate their "creativity". They are required to hand in poems, paintings, or drawings. As Miss Emily says, "your art would reveal what you were like, it would reveal your souls. We did it to prove you had souls at all" 
(Ishiguro, 2006, p. 260). Even if clones show their artistic talents to be wholly like human beings' (which, on the other hand, shows that clones have souls), their fate cannot change at all. In Chapter 22, after Tommy finished his two donations, he and Kathy heard a "Rumor"- Hailsham students can defer the organ donation as long as they could prove they are "properly in love", and show creative artistic works to the head of Hailsham. To this end, Kathy and Tommy took Tommy’s “drawing” to Hailsham's former headmistress "Madame” and guardian Miss Emily. Nevertheless, it turned out to be a fake rumor—Tommy failed to get permission of "deferral”. Emily's answer broke their last hope:

And for a long time, people preferred to believe these organs appeared from nowhere, or at most that they grew in a kind of vacuum... There was no way to reverse the process. There was no going back. However uncomfortable people were about your existence, their overwhelming concern was that their own children, their spouses, their parents, their friends, did not die from cancer, motor neurone disease, heart disease. (Ishiguro, 2006, p. 262)

Hypothetically taking the stand of human beings, Miss Emily explained to Kathy and Tommy the reasons that human beings ignored the existences and sufferings of clones. She stated that "the world didn't want to be reminded how the donation programme really worked. They didn’t want to think about you students, or about the conditions you were brought up in” (Ishiguro, 2006, p. 264). After the World War II, there emerged new possibilities and solutions to previously incurable diseases with the great breakthroughs in science sprung up rapidly. But according to Miss Emily, "the world” (refer to some scientists) showed eager pursuit of curable measures deviated from genuine scientific spirits like human cloning, in regardless of considering sensibly about ethical or unethical, moral or immoral, legal or illegal issues. Kathy and Tommy decided to accept their mission of organ donation after their final hope was disillusioned, because "in fact, they see donation as an ethical responsibility that is deeply rooted in their hearts and makes them 'silent victims'...Donation or death is inescapable, and is their fate” (Du, 2014, p. 66).

In the novel, Clones are characterized as human beings having emotions and even suffering emotional predicaments. They are all caught in solitude and despair in respective roles, but still long for love and comfort. As the narrator, Kathy is also a "Carer”, whose work is to look after the clone donors every day. It is an extremely brutal job to watch clones' dying all the time. In Chapter 18, Kathy expresses her loneliness in this special duty:

Then there's the solitude. You spend hour after hour, on your own, driving across the country, centre to centre, hospital to hospital, sleeping in overnights, no one to talk to about your worries, no one to have laugh with...You're always ins rush, or else you're too exhausted to have a proper conversation. (Ishiguro, 2006, p. 207)

Apart from the depiction of the love of Tommy and Kathy, the novel designs that Ruth gets involved in the couple’s affair because of loneliness and jealousy. Kathy's beloved Tommy is isolated, bullied, and teased by his classmates since childhood in Hailsham. Teachers take little care of his inner world, which makes him a shy and introverted boy, while Kathy is the only friend who cares deeply about him. Regrettably, he never confesses his real love to Kathy but turns to accept love from Ruth, which plunges Kathy into a deep ocean of anguish. To enhance the exactness between human and human clones, the novel exquisitely weaves the predicaments of the three characters' tangled love with bitterness. In spite of being portrayed identically as human beings, human clones remain dehumanized in terms of their organ donation missions. 


\section{Alienation of Clones}

In Never Let Me Go, due to human's violation of the principles of bioethics, clones are alienated as the counterpart of human beings - "the other". The alienation of clones is revealed in the process of being dehumanized and evaluated. All clones aresent to boarding school "Hailsham” since infancy and are alienated from the outside world before "graduation". After leaving Hailsham at the age of 16 and moving to a place called "Cottages", clones are exposed to the outside world and given some limited freedom. It causes human clones to question their existence and their relationship with human beings. Ruth is a case in point. Having experienced the human world in the "cottages" and caught a sight of a human woman looked exactly like her, she awakened that she's just a clone model of human beings. Ruth collapsed and shouted to her fellow clones:

We all know it. We're modeled from trash. Junkies, prostitutes, winos, tramps. Convicts, maybe, just so long as they aren't psycho. That's what we come from. We all know it, so why don't we say it... We know it, so we might as well just say it. If you want to look for possibles, if you want to do it properly, then you look in the gutter. You look in rubbish bins. Look down the toilet, that's where you'll find where we all came from. (Ishiguro, 2006, p. 166)

Ruth's self-derogatory words made her fellow clones feel belittled and inferior to human beings, thus drawing a sharp line between human beings and human clones. This boundary is strongly convinced in teacher Miss Emily's comments on how human beings view clones in Hailsham:

So for a long time you were kept in the shadows, and people did their best not to think about you. And if they did, they tried to convince themselves you weren't really like us. That you are less than human, so it didn't matter...there would always be a barrier against seeing you as properly human. (Ishiguro, 2006, p. 263)

Judging from another angle, after having realized the truth of being clonedas in Ruth's self-confession, clones arose a fierce feeling of self-debasement. It lets clones accept submissively their doomed fate, whereas makes human beings be more arrogant in the organ-removal actions.

Teacher Miss Lucy once taught clone students in Hailsham, "You've been told about it. You are students, you're...special” (Ishiguro, 2006, p. 68). Each name of clone students is composed of a given name (like Peter, Mathew, and Ruth) and a followed English letter (like A, B, and J). The clone names differ from regular human names and read like the codes designed for robots, as in Kathy H, Jenny B, Graham K, Alexander J, and Peter N and so on. The act of coding clones is a manifestation of making them to be objectified. Objectification is a means of alienating clones. Another example of the objectification of clones is the scene that Tommy got the gash on his elbow. On seeing the open wound on Tommy’s elbow, Christopher said nonchalantly:

Don't you know? If it's right on the elbow like that, it can unzip. All you have to do is bend your arm quickly. Not just that actual bit, the whole elbow, it can all unzip like a bag opening up. Thought you'd know that. (Ishiguro, 2006, p. 85)

Here, clone's body is regarded as “a bag”, and the word "unzip” implies that clone's body is merely an object or a container. In a conversation with guardian Miss Emily, Kathy showed a plaint, "Madame never liked us. She's always been afraid of us. In the way people are afraid of spiders and things" (Ishiguro, 2006, p. 268). And later, the headmistress "Madame” responded to Kathy, "You poor creatures" (Ishiguro, 2006, p. 272). All these conversations illustrate that "the students of Hailsham are never directly mentioned as lesser creatures or described with any insulting terms but it is nonetheless clear from instances there is indeed a heavily implied 
sense of difference" (Kate, 2012, p. 414). In the novel, through the effective measures of body cloning, name coding, education infusing, behavior isolating, and emotion controlling, etc., human beings have completed their objectification and alienation to human clones. Human clones have been modeled and tamed, and in turn, to subserviently serve for the benefits of human beings.

\section{Conclusion}

By interpreting Never Let Me Go in the context of posthumanism, this essay discusses the dominate themes of the novel that human beings entrapped clones in existential predicaments and violated bioethical principles to usurp clones'organs. The novel reveals the fact that the emergence of human cloning is due to heavy causalities caused by World War II when human beings haunted by the fear of death and began to fixate on the development of science and technology and managed to prolong their lives. It prompts people to ponder on the relationship between high techs and ethics in the future, and furthers a suggestion of moral turpitude and ethical lapse of anthropocentric worldview held by humans in posthumanist period. These cautionary insights owe to Kazuo Ishiguro's creative inspiration rooted in social and historical backgrounds. With acute discernment, Ishiguro writes in a postmodernist era when the rapid booming inscience and technology opened a new literary scope. His artistic endeavors are more than making people obtain literary flair, rather, suggesting people to make observations beyond superficial phenomena, as in his own words, "to 'plumb the depths and shallows' of the 'emotional upheaval'” (Shaffer \& Wong, 2008, p. 57). By his moral and literary expressions to depict the tragic fate of human clones in Never Let Me Go, Ishiguro demonstrates profound concerns about the consequences of misusing of science and technology in the posthumanist era. His views, to a great extent, conform to philosopher Nikola Danaylov's manifestation in his Transhumanist Manifesto, "We must all respect autonomy and individual rights of all science throughout the universe, including humans, non-human animals, and any future AI, modified life forms, or other intelligences" (Danaylov, 2016, p. iii).

\section{References}

Beauchamp, T., \& Childress, J. (2013). Principles of biomedical ethics (7th ed.). New York: Oxford University Press.

Bendle, M. (2002). Posthuman ideology. Social Semiotics, 12(1), 45-62.

Danaylov, N. (2016). A transhumanist manifesto [redux]. Retrieved April 3, 2019 from https://www.singularityweblog.com

DeGrazia, D. (2003). Common morality, coherence, and the principles of biomedical ethics. Kennedy Institute of Ethics Journal, 13(3), 219-230.

Du, Y. M. (2014). An ethical literary analysis of Never let me go. Foreign Literature Studies, (3), 60-67.

Grrifin, G. (2009). Science and the cultural imaginary: The case of Kazuo Ishiguro’s Never let me go. Textual Practice, 23(4), 645-663.

Harari, Y. N. (2017). Homo Deus: A brief history of tomorrow. (J. H. Lin, Trans.). Beijing: China Critic Press.

Ishiguro, K. (2006). Never let me go. New York: A Division of Random House, Inc. First Vintage International Open-Market Edition.

Kashi, S., \& Ladani, Z. J. (2017). The representation of Fukuyama's pathways to a posthuman future in Brave new world and Never let me go. Journal of Literary Studies, 33(2), 18-34.

Kevin, D. (Jannuary 21, 2019). CRISPR babies researcher He Jiankui fired in wake of investigation. Retrieved March 10, 2019 from https://www.clinicalomics.com

Kate, G. (August 22, 2012). The construction of otherness in Kazuo Ishiguro’s Never let me go. Retrieved April 8, 2019 from https://www.academia.edu.com

Li, L., \& Wang, J. (2014). Nowhere to run in Never let me go. Journal of Zhengzhou Institute of Aeronautical Industry Management (Social Science Edition), 33(1), 77-80. 
Mazullo, M. (2012). Alone: Kazuo Ishiguro and the problem of musical empathy. The Yale Review, 100(2), 78-98.

Miah, A. (2009). A critical history of posthumanism. Medical Enhancements \& Posthumanity, (1), 72-94. New York: Routledge. More, M. (1994). On becoming posthuman. Free Inqury, 14(4), 38-41.

Pandey, A. (2011). “Cloning words”: Euphemism, neologism and dysphemism as literary devices in Kazuo Ishiguro’s Never let me go. Studies in Culture and Education, 18(4), 383-396.

Quach, M. (2017). The complexity of love and friendship in Kazuo Ishiguro’s Never let me go: An actantial analysis (Dissertation, Karlstad University).

Robbins, B. (2007). Cruelty is bad: Banality and proximity in Never let me go. Novel, 40(3), 289-302

Roos, H. (2008). Not properly human: Literary and cinematic narrative about human harvesting. Journal of Literary Studies, 24(3), 40-53.

Shaffer, B. W., \& Wong, C. F. (2008). Understanding Kazuo Ishiguro. Columbia: University of South Carolina Press.

Steven, B. (2005). Ethics, technology, and posthuman communities. Essay in Philosophy, 6(1), 1-17.

Su, K., \& Huang, Y. (2014). The textual function of analects presuppositions in Kazuo Ishiguro's Never let me go. Contemporary Foreign Languages Studies, (1), 60-65.

The Nobel Prize in Literature 2017. (2019). NobelPrize.org. Nobel Media AB 2019. Retrieved Apr. 19, 2019 from http://www.nobelprize.org/prizes/literature/2017/summary/

Tseng, C. F. (2011). Landscape in Kazuo Ishifuro's Never let me go. (Dissertation, National Kaohsiung Normal University).

Valera, L. (2014). Posthumanism: Beyond humanism? Cuadernos de Bioetica, XXV(3), 481-491.

Vichiensing, M. (2017). The othering in Kazuo Ishiguro's Never let me go. Advances in Language and Literary Studies, (4), 126-135.

Wang, K. Y. (2014). Anxiety of “stay” and “leave” in Don’t let me go. Journal of Wenzhou Vocational \& Technical College, 14(4), 64-67.

Xin, H. M. (2012). The posthuman in Kazuo Ishiguro’s Never let me go. Contemporary Foreign Literature, (4), 129-136.

Zhang, L. Y. (2014). An analysis of Never let me go from the perspective of existentialism (Dissertation, Zhengzhou University). 